strategische-agenda-hoger-onderwijs-en-onderzoek-houdbaar-voor-detoekomst

Tax reduction for study costs or other education related expenditures: Netherlands. (2020). Financing adult learning database. URL: https://www.cedefop.europa.eu/en/publications-and-resources/tools/ financing-adult-learning-db/search/tax-reduction-study-costs-or-othereducation-related

Testo Unico delle Imposte sui Redditi. (2021). URL: https://www.altalex.com/documents/codici-altalex/2014/12/10/tuir-testounico-delle-imposte-sui-redditi

УДК 374.7.01:001.891

DOI: https://doi.org/10.35387/od.2(20).2021.40-50

$\begin{array}{lrl}\text { Лапаєнко Світлана } & \text { Lapaienko Svitlana - Candidate } \\ \text { Володимирівна - кандидат } & \text { of Pedagogical Sciences, Senior } \\ \text { педагогічних наук, старший } & \text { Research Fellow, Acting Head of } \\ \text { науковий співробітник, в.0. } & \text { the Department of Scientific } \\ \text { завідувача відділу наукового } & \text { Information and Analytical Support } \\ \text { інформаційно-аналітичного } & \text { of Education, V. O. Sukhomlynskyi } \\ \text { супроводу освіти Державної } & \text { State Scientific and Pedagogical } \\ \text { науково-педагогічної бібліотеки } & \text { Library of Ukraine } \\ \text { України } & \text { імені }\end{array}$

В. О. Сухомлинського

ORCID iD: http://orcid.org/0000-0002-0412-6618

E-mail: slapaenko@ukr.net

\title{
ОСВІТА ДОРОСЛИХ У НАУКОВОМУ ДИСКУРСІ ВЧЕНИХ НАПН УКРАЇНИ
}

Анотація. У статmі висвітлено основні наукові підходи вчених НАПН України щодо розвитку освіти дорослих (освіти впродовж життя) в Україні.

Охарактеризовано принцип людиноцентризму (В. Кремень), який в освіті дорослих передбачає сприяння розвитку особистості, самореалізації людини в особистому та професійному житті, підвищенню ї компетентності й конкурентоспроможності. Саме розвиток людини $\epsilon$ потужним чинником розвитку суспільства й економіки. Дотримання цього принципу забезпечує максимальне наближення освіти дорослих до освітньокультурних потреб і здібностей, життєвих планів особистості.

Обгрунтовано (Н. Ничкало), що створення відповідних умов для широкого залучення різних категорій дорослого населення до освіти впродовж життя, є ключовою умовою забезпечення конкурентоспроможності на ринку праці, що закономірно посилює роль освіти дорослих у розвитку сучасного суспільства на основі андрагогічно орієнтованих підходів до навчання в нових умовах цифрового суспільства.

З'ясовано (Л. Лук'янова), що на сучасному етапі розвитку освіти 
дорослих необхідне створення ї̈ нової моделі, яка має передбачати адекватні й варіативні умови для участі у процесах неперервної освіти, набуття нових загальних $i$ професійних знань, цінностей $i$ компетентностей, які сприятимуть універсалізації дорослої людини в сучасних соціокультурних умовах, а також формуванню світоглядних прагнень, активізації їі участь у розвитку інститутів суспільства.

Акцентовано увагу (О. Аніщенко) на взаємодоповнюваності формальної, неформальної та інформальної освіти дорослих. Підкреслено доцільність створення розгалуженої мережі закладів неформальної освіти, у тому числі й центрів освіти (і навчання) дорослих.

Досліджено (С. Сисоєва), що навчання дорослої людини повинно здійснюватися за андрагогічною моделлю навчання, 3 урахуванням психологічних особливостей навчання дорослого; перевага повинна надаватися інтерактивним технологіям навчання, які найбільш ефективно забезпечують комунікаційні зв'язки, сприяють утвердженню партнерських відносин, урахування професійного і життєвого досвіду суб'єктів педагогічної взаємодії.

Ключові слова: освіта дорослих; андрагогіка; освіта упродовж життя; особистісний і профресійний розвиток; інтерактивні технології.

Lapaienko Svitlana

\section{ADULT EDUCATION IN SCIENTIFIC DISCOURSES OF SCIENTISTS OF THE NAES OF UKRAINE}

Abstract. The article highlights the main scientific approaches of scientists of the NAES of Ukraine on the development of adult education (lifelong learning) in Ukraine.

The principle of anthropocentrism (V. Kremen) is described, which in adult education provides for the promotion of personal development, human selfrealization in personal and professional life, increasing its competence and competitiveness. It is human development that is a powerful factor in the development of society and economy. Adherence to this principle ensures the maximum approximation of adult education to the educational and cultural needs and abilities, life plans of the individual.

It is substantiated (N. Nychkalo) that the creation of appropriate conditions for the broad involvement of various categories of adults in lifelong learning is a key condition for competitiveness in the labor market, which naturally strengthens the role of adult education in modern society based on andragogically oriented approaches to learning. new conditions of the digital society.

It was clarified (L. Lukyanova) that at the present stage of development of adult education it is necessary to create a new model, which should provide adequate and varied conditions for participation in the processes of continuing education, acquisition of new general and professional knowledge, values and competencies. will contribute to the universalization of the adult in modern sociocultural conditions, as well as the formation of worldview aspirations, intensifying its participation in the development of institutions of society.

Emphasis is placed (O. Anishchenko) on the complementarity of formal, non-formal and informal adult education. The expediency of creating an extensive 
network of non-formal education institutions, including adult education (and training) centers, is emphasized.

It is investigated (S. Sysoeva) that adult learning should be carried out according to the andragogical model of learning, taking into account the psychological features of adult learning; Preference should be given to interactive learning technologies that most effectively provide communication, promote the establishment of partnerships, taking into account the professional and life experience of the subjects of pedagogical interaction.

Key words: adult education; andragogy; lifelong education; personal and professional development; interactive technologies.

Постановка проблеми, її актуальність. Освіта дорослих як складова освіти впродовж життя розглядається як один із основних факторів сталого розвитку особистості та суспільства. Тенденції суспільного розвитку значною мірою пов'язані 3 модернізацією та реформуванням системи освіти в Україні, що здійснюється в напрямі їі демократизації та гуманізації, урахування світових і європейських стандартів якості при збереженні національних здобутків і пріоритетів. За таких умов проблеми функціонування та розвитку освіти дорослих набувають особливої актуальності. Аналіз наукових джерел та освітньої практики дає можливість встановити, що сучасною дійсністю є онлайннавчання дорослих, цифрове середовище, яке має високий потенціал для підвищення рівня їхньої індивідуальної та групової участі в освітньому процесі. Активно реалізуються програми безперервної освіти (навчання протягом життя - lifelong learning) на підґрунті таких принципів освіти дорослих як: орієнтації на створення у країні єдиної системи безперервної освіти; визнання права на освіту в будь-якому віці як одного 3 найважливіших фундаментальних прав людини; орієнтації на загальнолюдські цінності та ідеали гуманізму; сприяння гармонізації інтересів особистості, соціуму та суспільства в цілому; забезпеченні доступності освіти; взаємодії та державно-приватного партнерства; всебічна підтримка громадської ініціативи тощо.

У системі освіти дорослих реалізується певна частка єдиного процесу безперервної освіти. До її структури входять мережа закладів освіти, соціальні служби, просвітницькі організації, установи науки та культури; ресурсні, культурно-дозвільні та моніторингові центри, засоби масової інформації; органи управління на національному, регіональному та місцевому рівнях. Серед найважливіших функцій освіти дорослих варто виділити такі: компенсаторну, що надає дорослим відсутню або втрачену можливість отримати освіту бажаного профілю та рівня; адаптуючу, що дозволяє опанувати нові компетентності, потреба у яких виникає в міру зміни професійної діяльності чи соціальних умов життєдіяльності; розвиваючу, яка сприяє особистісному зростанню людини завдяки освоєнню нового культурного простору. Проте потрібно відзначити, що в країні ще не забезпечено стійку позитивну динаміку масової участі дорослого населення у програмах навчання та тренінгів. Особливо 
актуальною також $€$ необхідність наукового забезпечення процесу розробки та апробації сучасних технологій навчання дорослих, удосконалення його змісту як найважливішої та недостатньо розвиненої ланки системи безперервної освіти. Таким чином, освіта дорослих сьогодні мусить стати тим важелем, який визначатиме характер функціонування та розвитку різних галузей, які є важливими для відповіді на актуальні виклики сьогодення.

Аналіз актуальних досліджень і публікацій. Останніми роками активізувалися наукові розробки проблем навчання дорослих, представлені, зокрема, в працях провідних учених Національної академії педагогічних наук України: фрілософські й теоретико-методологічні основи освіти дорослих у системі неперервної освіти (В. Андрущенко, І. Бех, С. Болтівець, І. Зязюн, В. Кремень, В. Луговий, Л. Лук'янова, С. Ніколаєнко, Н. Ничкало, С. Сисоєва, Л. Сігаєва, М. Солдатенко, Г. Філіпчук та ін.); андрагогічні основи післядипломної професійної освіти (В. Аніщенко, В. Олійник, В.Пуцов, В. Радкевич та ін.); освіта дорослих в умовах глобалізаційних та євроінтеграційних процесів, порівняльна андрагогіка (Н. Авшенюк, Н. Бідюк, Т. Десятов, О. Огієнко, О. Сухомлинська, І. Фольварочний та ін.).

Мета статті - проаналізувати творчий доробок вчених Національної академії педагогічних наук України з проблем освіти дорослих для інформування як педагогічної спільноти, так і громадськості 3 означеної проблеми та сприяння покращенню інформаційно-аналітичного супроводу освіти й науки.

Виклад основного матеріалу дослідження. У полі зору вчених Національної академії педагогічних наук України (далі - НАПН України) постійно знаходяться проблеми оновлення методологічних та теоретикометодичних підходів щодо модернізації та реформування української системи освіти у сучасному інформаційному контексті. Свідченням цього $є$ сфрормовані «Пріоритетні напрями (тематика) наукових досліджень та науково-технічних (експериментальних) розробок НАПН України на 20182022 рр.» (2017) та увага до розвитку наукових досліджень, упровадження їх результатів та інноваційного досвіду щодо навчання різних категорій дорослих; проблем неперервної освіти, підготовки науково-педагогічних (педагогічних) працівників до роботи в адрагогічному середовищі, профресійного навчання i перенавчання дорослих в умовах трансформаційних змін економіки, консультативної діяльності для професійної кар'єри дорослих. Так, десятий пріоритетний напрям наукових досліджень «Освіта дорослих. Післядипломна освіта» містить такі актуальні проблеми: становлення і розвиток освіти дорослих в Україні; методологічні, теоретичні, методичні засади розвитку освіти різних категорій дорослих в умовах глобалізаційних та інтеграційних процесів; прогнозування і проєктування освіти дорослих; розвиток регіональної і галузевої освіти дорослих; місце і роль інституцій громадянського суспільства в розвитку освіти дорослих; сучасні технології навчання дорослих для професійної діяльності тощо. 
В європейській стратегії «Європа 2020» (EUROPE, 2020) освіта та навчання впродовж життя розглядаються як ключові чинники створення конкурентної і динамічної європейської економіки, що базується на знаннях. Декларується, що освіта дорослих $€$ необхідною передумовою покращення соціального стану, формування громадянської позиції, особистісної і профресійної реалізації та підвищення можливостей зайнятості; підкреслюється необхідність розвитку індивідуальних здібностей і потенціалу людей.

В. Кремень у доповіді «Педагогічна специфріка освіти дорослих» на Всеукраїнському Форумі «Україна 30. Освіта і наука» (Кремень, 2021) актуалізував проблему освіти дорослих, що зумовлено переходом людства до нового - інноваційного типу прогресу. До ключових функцій, які зазнають трансформації, віднесено: навчання людини навчатися впродовж життя та навчання використовувати отримувані знання в практиці. Представлено нові завдання задля формування інноваційної людини і забезпечення ії конкурентоспроможності, а саме: усвідомлення освіти дорослої людини як єдиного шляху до її саморозвитку, самовдосконалення і досягнення життєвого успіху; створення механізмів спонукання до освіти на рівні держави, окремих підприємств і установ та фрормування розгалуженого ринку освітніх послуг для дорослих; підготовка викладачів для освіти дорослих; необхідність здійснення науково-методичного забезпечення освіти дорослих; створення центрів з визнання результатів неформальної та інформальної освіти. Звернуто увагу на позитивний досвід з питань освіти дорослих, здобутий у системі НАПН України, зокрема в Інституті педагогічної освіти і освіти дорослих імені Івана Зязюна та Університеті менеджменту освіти (Кремень, 2021).

Філософрські засади розвитку освіти дорослих. 3 огляду на динамічні глобалізаційні процеси, що відбуваються у сучасному світі, Н. Ничкало акцентує увагу на тому, що розвиток освіти дорослих набуває сьогодні міжнародного значення й особливої актуальності. Адже цей процес детермінується соціально-економічними перетвореннями, нагальними потребами навчання, перепідготовки і підвищення кваліфікації, професійного розвитку різних категорій дорослого населення. Створення у нашій державі відповідних умов для широкого залучення різних категорій дорослого населення до освіти впродовж життя, наголошує Н. Ничкало, $€$ ключовою умовою забезпечення конкурентоспроможності на ринку праці, що закономірно посилює роль освіти дорослих у розвитку сучасного суспільства на основі андрагогічно орієнтованих підходів до навчання в нових умовах цифрового суспільства (Ничкало, 2020).

За В. Кременем, принцип людиноцентризму, на якому ґрунтується сучасна фрілософрія освіти, в освіті дорослих передбачає сприяння розвитку особистості, самореалізації людини в особистому та професійному житті, підвищенню ії компетентності й конкурентоспроможності. Саме розвиток людини $€$ потужним чинником розвитку суспільства й економіки, тому принцип людиноцентризму має стати базовим у змісті формальної і нефрормальної освіти. Дотримання цього принципу забезпечує 
максимальне наближення освіти дорослих до освітньо-культурних потреб і здібностей, життєвих планів особистості (Кремень, 2018).

Концептуальні основи освіти дорослих в Україні. Упродовж останніх років в українському суспільстві помітно посилилася увага до проблем, які пов'язані з освітою дорослих. На нашу думку, цей процес детермінується потребами громадян на неперервну освіту впродовж життя, iï спрямуванням на гармонізацію інтересів особистості, створенням необхідних умов її духовного розвитку та реалізації набутого життєвого і професійного потенціалу. Розроблена Л. Лук'яновою «Концепція освіти дорослих в Україні» (Лук'янова, 2011) спрямована на подолання суперечностей між об'єктивною потребою розвитку навчання дорослих у системі формальної, неформальної й інформальної освіти та нерозробленістю належного нормативно-правового, науково-методичного, організаційного забезпечення; необхідністю врахування потреб ринку праці, вимог роботодавців, а також освітньо-культурних потреб дорослих, мотиваційних, ціннісних орієнтацій дорослих громадян щодо особистісної самореалізації та відсутністю сучасних технологій їхньої професійної підготовки і перепідготовки; зрослими вимогами роботодавців до рівня професійної компетентності працівників і відсутністю комплексної науково обґрунтованої системи організації їхньої професійної перепідготовки. У «Концепції освіти дорослих в Україні» освіта дорослих визначається як складова системи неперервної освіти, метою якої $€$ соціально-економічна адаптація дорослої людини до перетворень, що відбуваються у суспільстві; пролонгований процес і результат розвитку й виховання особистості засобами реалізації освітніх програм і послуг упродовж життя. Найбільш значущими концептуальними засадами розвитку освіти дорослих $є$ : філософсько-педагогічна ідея неперервності освіти, законодавче забезпечення освіти дорослих, положення професіоналізації освіти дорослих (Лук'янова, 2018). Нам імпонують висновки науковців про необхідність «створення цілісної, гнучкої, відкритої національної системи освіти дорослих, що поєднує формальну, неформальну, інформальну освіту, спрямовану на задоволення поточних і перспективних освітніх потреб особистості» (Лук'янова, Аніщенко, \& Москаленко, 2019).

На сучасному етапі розвитку освіти дорослих актуалізувалася необхідність створення ії нової моделі. Так, сучасна модель ґрунтується на визнанні дорослої людини як суб'єкта, безумовно, здатного до освіти, проте реальне життя показує, що у дорослих мають місце дискретні освітні періоди, які виникають унаслідок впливу економічних, суспільних і політичних криз. Нова модель має передбачати сенс дорослих в системі освіти не тільки як апріорно універсального суб'єкта з необмеженими здатностями, але й ураховувати кризи психічного, соціокультурного розвитку людини, яка відчуває та усвідомлює певні спади, що перешкоджають їі освіті й розвитку. Адже через реальну соціокультурну ситуацію доросла людина, на відміну від дитини, перебуває у несприятливих умовах (професійна зайнятість, соціальна відповідальність, перенавантаження, низький рівень винагороди за роботу, постійна 
стресогенність), що створює необхідність збереження фрізичного, психічного й соціального здоров'я дорослої людини. Нова модель освіти дорослих має також передбачати адекватні й варіативні умови для участі у процесах неперервної освіти, набуття нових загальних і професійних знань, цінностей і компетентностей, які сприятимуть універсалізації дорослої людини в сучасних соціокультурних умовах, а також формуванню світоглядних прагнень, активізації іï участь у розвитку інститутів суспільства (Лук'янова, 2018).

О. Аніщенко розроблено «Концепцію розвитку неформальної освіти дорослих в Україні» (2019), яка, на думку автора, сприятиме посиленню професіоналізації освіти дорослих в Україні, визнанню на рівні держави, регіонів і громад, індивідуальному рівні важливості й необхідності розвитку неформальної освіти дорослих; розвитку неформальної освіти як невід'ємної складової національної системи освіти; підтримці освітніх ініціатив закладів неформальної освіти щодо особистісного і професійного зростання різних категорій дорослих. У Концепції розвитку неформальної освіти дорослих в Україні наголошується, що неформальна освіта дорослих передбачає цілеспрямований процес навчання, виховання й розвитку дорослих шляхом реалізації варіативних освітніх програм, надання додаткових освітніх послуг у приватних і державних закладах освіти, установах, громадських та інших організаціях, на підприємствах тощо. На наше переконання, науковцем слушно акцентовано увагу на необхідності забезпечення відповідності ринку освітніх послуг і ринку праці, використання ресурсів неформальної та інформальної освіти через визнання результатів попереднього навчання, поширення дистанційних форм навчання тощо. О. Аніщенко цілком логічно обґрунтовано доцільність узгодження та гармонізації освітньої діяльності провайдерів освітніх послуг у сорері неформальної освіти дорослих. Важливого значення набуває те, що автором обґрунтовано нагальність розроблення, затвердження та впровадження регіональних програм, стратегій, стратегічних планів розвитку освіти дорослих, в яких необхідно передбачити розвиток неформальної освіти як її невід'ємної складової. Підкреслено доцільність створення розгалуженої мережі закладів неформальної освіти, у тому числі й центрів освіти (і навчання) дорослих. Акцентовано увагу на взаємодоповнюваності формальної, неформальної та інформальної освіти дорослих (Аніщенко, 2019).

Андрагогічна технологія, організація простору освіти дорослих. Технології навчання дорослих (Сисоєва, 2011) - це способи реалізації змісту освіти дорослих, оптимальні й ефективні для віку та фізичного стану дорослої людини, що передбачають взаємодію змістової, процесуальної, мотиваційної, організаційної складових. Навчання дорослої людини має низку специфічних ознак i особливостей. Передусім воно має здійснюватися за андрагогічною моделлю навчання, 3 урахуванням психологічних особливостей навчання дорослого, а, по-друге, перевага повинна надаватися інтерактивним технологіям навчання як такому способу організації їх навчально-пізнавальної діяльності, що здійснюється 
з урахуванням інтересів і запитів, життєвого і професійного досвіду учнядорослого у формах партнерської взаємодії всіх суб'єктів навчального процесу. Інтерактивне навчання дорослих спрямоване на забезпечення спільного процесу пізнання, отримання знань, умінь, навичок, здобуття необхідних компетенцій у спільній діяльності через діалог, полілог учнівдорослих між собою й викладачем, а також через пряму взаємодію 3 навчальним оточенням або навчальним середовищем, що забезпечує високий рівень мотивації до навчання і моделює реальність, у якій учасники знаходять для себе галузь застосування набутого досвіду (Сисоєва, 2018). Інтерактивне навчання - це застосування сучасних інфрормаційних технологій у навчанні, дистанційної фрорми освіти 3 використанням ресурсів Інтернету, а також електронних підручників, довідників тощо.

Л. Лук'янова у дослідженні «Освіта впродовж життя в умовах інфрормаційно-технологічного суспільства» (Лук'янова, 2019) на основі інноваційного та технологічного підходів зазначає, що результат освіти впродовж життя можна представити на трьох рівнях: індивідуальному, рівні підприємства чи організації та рівні суспільства. Індивідуальний рівень уособлює сукупність позитивних змін, серед яких - зростання рівня задоволеності працею, поліпшення стану здоров'я та відчуття благополуччя, збільшення шансів працевлаштування й зростання заробітку, кар'єрного зростання, можливість зміни місця праці або професії тощо. Науковцем обгрунтовано висновок про те, що на рівні установи (організації) зростає продуктивність праці, підвищується відповідальність працівників, рівень їх адаптованості до інновацій, поліпшується соціальнопсихологічний клімат у колективі. Підкреслено, що на рівні суспільства відбувається зростання економіки, підвищується економічна активність населення, продовжуються вікові межі трудової діяльності тощо.

В. Луговий і Ж. Таланова (Луговий, \& Таланова, 2018) на основі аналізу досвіду створення, функціонування й розвитку просторів освіти $\mathrm{i}$ досліджень, узагальнення механізмів їх побудови сформулювали засади системної організації простору освіти дорослих. Як свідчить аналіз цитованої праці, йдеться про: єдність усіх трьох видів освіти - формальної, неформальної та інформальної; мати тривимірну структуру - рівневу, орієнтаційну, галузеву; запровадження базової кодифікації освітніх програм (курсів) та отриманих кваліфікацій (компетентностей); створення системи забезпечення якості освіти дорослих, що передбачає програмну та інституційну акредитацію; створення і підтримка Єдиного електронного реєстру усіх кодифікованих, кредитованих та акредитованих освітніх програм (курсів) та відповідних кваліфікацій (компетентностей); моніторинг стану і розвитку простору освіти дорослих запровадження системи збирання й адміністрування статистичних даних, доступних онлайн; роботодавці мають бути вмотивовані до реалізації освіти дорослих шляхом законодавчих зобов'язань щодо її фінансування (як частки фонду оплати праці).

Висновки і перспективи подальших досліджень. Аналіз 
основних наукових розробок вчених НАПН України, засвідчує, що освіта дорослих сприяє особистісному розвитку індивіда, формує готовність людини до співпраці, відповідальності, прийняття виважених рішень. Соціальне значення освіти протягом усього життя полягає у сприянні розвитку толерантності та готовності до життєдіяльності у відкритому полікультурному суспільстві. У плані економічної перспективи освіта дорослих виконує функцію формування готовності індивіда до раціонального споживання, підтримки підприємництва, економічної успішності, сталого розвитку. У контексті культурного розвитку на освіту дорослих покладається завдання збереження та розвитку національних, культурних та освітніх традицій, соціальних норм поведінки та цінностей. Серед основних цілей освіти дорослих - розширення освітніх можливостей для дорослих громадян, створення середовища для постійного вдосконалення особистості, її адаптації до соціально-економічних змін в країні та у світі; сприяння кожній людині незалежно від вікової, статевої приналежності, рівня отриманого освіти, соціального досвіду відчувати себе активною рушійною силою суспільного розвитку.

Доробок учених НАПН України - фрілософські, управлінські, гуманітарні, культурологічні і психолого-педагогічні ідеї та погляди на освіту дорослих - засвідчив, що традиційна система освіти дорослих вступила в суперечність із суспільним розвитком, не відповідає його потребам. Тому, безумовно, викликом та відкриттям нових перспектив для освіти дорослих $є$ цифрові технології, що змінюють економічне, політичне, соціальне та культурне життя. У цьому контексті наукові праці В. Кременя, В. Лугового, Л. Лук'янової, Н. Ничкало, С. Сисоєвої та ін. дозволяють конкретизувати мету, завдання, зміст освіти дорослих, а саме: сприяння розвитку особистості людини, поступальне нарощування професійних компетентностей та підвищення творчого потенціалу, збагачення особистісно-значущими знаннями та вміннями.

Підкреслимо (Кремень, 2018), що у суспільстві знань освіта дорослих як складник неперервної освіти впродовж життя входитиме до життєвої парадигми особистості, забезпечуватиме підготовку особистості до успішної життєдіяльності в особистому й професійному аспектах в умовах трансформаційних змін. Аби не відстати від прогресивних змін, людина має формуватися як така, для якої знання $€$ основою життя й діяльності, методологією пошуку й ухвалення рішень.

Розвиток освіти дорослих в Україні потребує створення необхідних умов для підготовки андрагогів у закладах вищої освіти, що $\epsilon$ перспективою наших подальших наукових розвідок.

\section{Список використаних джерел}

Аніщенко, О. В. (2019). Концепція розвитку неформальної освіти дорослих в Україні. Освіта дорослих: теорія, досвід, перспективи, 1(15), 20-39. URL: http://www.adulteducationjournal.com.ua/index.php/aej/article/view/89

Кремень, В.Г. (2018). Освіта дорослих у вимірах людиноцентризму (передмова). Концептуальні засади розвитку освіти дорослих: світовий 
досвід, українські реалії і перспективи: збірник наукових статей. Київ: Знання України. 9-11.

Кремень, В. (2021). Педагогічна специфіка освіти дорослих. Доповідь на Всеукраїнському Форумі «Україна 30. Освіта і наука». URL: https://visnyk.naps.gov.ua/index.php/journal/article/view/156/199.

Луговий, В.ІІ, \& Таланова, Ж. В. (2018). Засади системної організації простору освіти дорослих / Концептуальні засади розвитку освіти дорослих: світовий досвід, українські реалії і перспективи: збірник наукових статей. Київ: Знання України. 12-21.

Лук'янова, Л. (2011). Концепція освіти дорослих в Україні. URL: https://lib.iitta.gov.ua/7529

Лук'янова, Л. Б., Аніщенко, О.В., \& Москаленко, Л.М.(2019). Концепція розвитку освіти дорослих в Україні. ГС «Українська асоціація освіти дорослих»; ІПООД імені Івана Зязюна НАПН України. Київ: ТОВ «ДКС Центр».

Лук'янова, Л. (2019). Освіта впродовж життя в умовах інформаційнотехнологічного суспільства. Освіта дорослих: теорія, досвід, перспективи. 1 (15). 10-20.

Ничкало, Н. (2020). Розвиток освіти дорослих на фрілософрсько-педагогічних засадах андрагогіки. Освіта дорослих: світові тенденції, українські реалії та перспективи : монографія. Харків: ФОП Бровін О.В. 12-23.

Пріоритетні напрями (тематика) наукових досліджень та науково-технічних (експериментальних) розробок НАПН України на 2018-2022 рр. (2017). URL: http://naps.gov.ua/ua/press/announcements/1315/

Сисоєва, С. О. (2011). Інтерактивні технології навчання дорослих: Навчальнометодичний посібник. Київ: ВД «ЕКМО».

Сисоєва, С. О. (2018). Інтерактивне навчання дорослих: теоретико-методичний аспект. / Концептуальні засади розвитку освіти дорослих: світовий досвід, українські реалії і перспективи: збірник наукових статей. Київ: Знання України. 52-59.

EUROPE 2020. A European strategy for smart, sustainable and inclusive growth. URL:http://ec.europa.eu/eu2020/pdf/COMPLET\%20EN\%20BARROSO $\% 20 \% 20 \% 20007 \%$.

\section{References (translated and transliterated)}

Anishchenko, O. (2019). Kontseptsiia rozvytku neformalnoi osvity doroslykh v Ukraini [The concept of non-formal adult education in Ukrain]. Osvita doroslykh: teoriya, dosvid, perspektyvy - Adult education: theory, experience, prospects. URL: http://www.adult-educationjournal.com.ua/index.php/aej/article/ view/89/52 [in Ukrainian].

Kremen, V. H. (2018). Osvita doroslykh u vymirakh liudynotsentryzmu (peredmova) [Adult education in the dimensions of anthropocentrism (preface)]. Kontseptualni zasady rozvytku osvity doroslykh: svitovyi dosvid, ukrainski realii i perspektyvy: zbirnyk naukovykh statei - Conceptual principles of adult education development: world experience, Ukrainian realities and prospects: a collection of scientific articles. Kyiv: Znannia Ukrainy - Kyiv: Knowledge of Ukraine, 9-11 [in Ukrainian].

Kremen, V. (2021). Pedahohichna spetsyfika osvity doroslykh. Dopovid na Vseukrainskomu Forumi «Ukraina 30. Osvita i nauka» [Pedagogical 
specifics of adult education. Report at the All-Ukrainian Forum «Ukraine 30. Education and Science»]. https://visnyk.naps.gov.ua/index.php/journal/article/view/156/199 [in Ukrainian].

Luhovyi, V. I., Talanova, Zh. V. (2018). Zasady systemnoi orhanizatsii prostoru osvity doroslykh [Principles of system organization of adult education space]. Kontseptualni zasady rozvytku osvity doroslykh: svitovyi dosvid, ukrainski realii i perspektyvy: zbirnyk naukovykh statei - Conceptual principles of adult education development: world experience, Ukrainian realities and prospects: a collection of scientific articles. Kyiv: Znannia Ukrainy - Kyiv: Knowledge of Ukraine, 12-21 [in Ukrainian].

Lukianova, L. (2011). Kontseptsiia osvity doroslykh v Ukraini [The concept of adult education in Ukraine]. URL: https://lib.iitta.gov.ua/7529 [in Ukrainian].

Lukianova, L. B., Anishchenko, O. V., \& Moskalenko, L. M. (2019). Kontseptsiia rozvytku osvity doroslykh $v$ Ukraini [The concept of adult education development in Ukraine]. HS «Ukrainska asotsiatsiia osvity doroslykh»; IPOOD imeni Ivana Ziaziuna NAPN Ukrainy. Kyiv: TOV «DKS Tsentr».

Lukianova, L. (2019). Osvita vprodovzh zhyttia v umovakh informatsiinotekhnolohichnoho suspilstva [Lifelong learning in an information technology society]. Osvita doroslykh: teoriia, dosvid, perspektyvy - Adult education: theory, experience, prospects. 1 (15), 10-20 [in Ukrainian].

Nychkalo, N. (2020). Rozvytok osvity doroslykh na filosofsko-pedahohichnykh zasadakh andrahohiky [Development of adult education on the philosophical and pedagogical principles of andragogy]. Osvita doroslykh: svitovi tendentsii, ukrainski realii ta perspektyvy : monohrafiia [Adult education: world trends, Ukrainian realities and prospects: a monograph]. Kharkiv: FOP Brovin OV, 12-23 [in Ukrainian].

Priorytetni napriamy (tematyka) naukovykh doslidzhen ta naukovo-tekhnichnykh (eksperymentalnykh) rozrobok NAPN Ukrainy na 2018-2022 rr. (2017). [Priority areas (topics) of scientific research and scientific and technical (experimental) developments of the National Academy of Pedagogical Sciences of Ukraine for 2018-2022]. URL: http://naps.gov.ua/ua/press/announcements/1315/ [in Ukrainian].

Sysoieva, S. O. (2011). Interaktyvni tekhnolohii navchannia doroslykh: Navchalnometodychnyi posibnyk [Interactive technologies of adult learning: A textbook]. Kyiv: VD «EKMO» [in Ukrainian].

Sysoieva, S. O. (2018). Interaktyvne navchannia doroslykh: teoretyko-metodychnyi aspekt [Interactive adult learning: theoretical and methodological aspect]. Kontseptualni zasady rozvytku osvity doroslykh: svitovyi dosvid, ukrainski realii i perspektyvy: zbirnyk naukovykh statei - Conceptual principles of adult education development: world experience, Ukrainian realities and prospects: a collection of scientific articles. Kyiv: Znannia Ukrainy - Kyiv: Knowledge of Ukraine, 52-59 [in Ukrainian].

EUROPE 2020. A European strategy for smart, sustainable and inclusive growth. URL: $\quad$ http://ec.europa.eu/eu2020/pdf/COMPLET\%20EN\%20BARROSO $\% 20 \% 20 \% 20007 \%$ [in English]. 